\title{
Selegiline: a molecule with innovative potential
}

\author{
Tamás Tábi ${ }^{1}$ (1) - László Vécsei ${ }^{2}\left([) \cdot\right.$ Moussa B. Youdim ${ }^{3} \cdot$ Peter Riederer $^{4,5} \cdot$ Éva Szökö $^{1}$ (])
}

Received: 2 August 2019 / Accepted: 10 September 2019 / Published online: 27 September 2019

(c) The Author(s) 2019

\begin{abstract}
Monoamine oxidase B (MAO-B) inhibitors have an established role in the treatment of Parkinson's disease as monotherapy or adjuvant to levodopa. Two major recognitions were required for their introduction into this therapeutic field. The first was the elucidation of the novel pharmacological properties of selegiline as a selective MAO-B inhibitor by Knoll and Magyar and the original idea of Riederer and Youdim, supported by Birkmayer, to explore its effect in parkinsonian patients with on-off phases. In the 1960s, MAO inhibitors were mainly studied as potential antidepressants, but Birkmayer found that combined use of levodopa and various MAO inhibitors improved akinesia in Parkinson's disease. However, the serious side effects of the first non-selective MAO inhibitors prevented their further use. Later studies demonstrated that MAO-B, mainly located in glial cells, is important for dopamine metabolism in the brain. Recently, cell and molecular studies revealed interesting properties of selegiline opening new possibilities for neuroprotective mechanisms and a disease-modifying effect of MAO-B inhibitors.
\end{abstract}

Keywords Selegiline $\cdot$ Monoamine oxidase type B inhibitors $\cdot$ Parkinson's disease $\cdot$ Dopamine $\cdot$ Neuroprotection

\section{Abbreviations}

$\begin{array}{ll}\text { ADL } & \text { Activity of daily living } \\ \text { MAO } & \text { Monoamine oxidase } \\ \text { ODT } & \text { Orally disintegrating tablets } \\ \text { PD } & \text { Parkinson's disease } \\ \text { STS } & \text { Selegiline transdermal system } \\ \text { UPDRS } & \text { Unified Parkinson's disease rating scale }\end{array}$

Tamás Tábi

tabi.tamas@pharma.semmelweis-univ.hu

1 Department of Pharmacodynamics, Semmelweis University, Nagyvárad tér 4, 1089 Budapest, Hungary

2 Department of Neurology, Interdisciplinary Excellence Centre, MTA-SZTE Neuroscience Research Group, University of Szeged, Faculty of Medicine, Albert Szent-Györgyi Clinical Center, Semmelweis u. 6, 6725 Szeged, Hungary

3 Technion-Rappaport Family Faculty of Medicine, Efron St, PO Box 9697, 31096 Haifa, Israel

4 Clinic and Polyclinic for Psychiatry, Psychosomatics and Psychotherapy, University Hospital Würzburg, Margarete-Höppel-Platz 1, 97080 Würzburg, Germany

5 Department of Psychiatry, University of South Denmark, Odense, Denmark

\section{History}

The story of the monoamine oxidase B (MAO-B) inhibitors started with the discovery of selegiline (R-deprenyl). The compound was synthesized by Zoltán Ecseri in Chinoin Pharmaceuticals (Budapest, Hungary) in 1962 along with a series of similar, structurally related drug candidates. Their pharmacology was thoroughly studied in the laboratories of Joseph Knoll at Semmelweis University (Budapest, Hungary) (Knoll and Magyar 1972; Magyar et al. 1979; Knoll 1979). They were looking for psychic energizers based on the known antidepressant effect of MAO inhibitors (Knoll et al. 1965). The first clinical study was performed according to this intended indication (Varga and Tringer 1967). However, Knoll and Magyar observed peculiar features of deprenyl different from those of previously used MAO inhibitors, e.g., it lowers blood pressure and is free from "cheese effect", the severe drug-food interaction of irreversible MAO inhibitor antidepressants. Namely, severe hypertensive crisis can develop when food rich in tyramine is consumed by patients treated by these drugs [for review see Finberg and Gillman (2011)]. The selective inhibitory effect of selegiline on one of the MAO isoforms was identified by Knoll and Magyar (1972). Parallel to their observation, Johnston published that the MAO enzyme exists in two distinct isoforms based on selective inhibition of one of them 
by clorgyline, which was named MAO-A (Johnston 1968). Selegiline, however, inhibits irreversibly the other isoform, and this was assigned as MAO-B. The other observation of Magyar was that the levorotatory isomer of the chiral deprenyl, R-deprenyl later called selegiline is a more potent inhibitor of MAO-B and has better pharmacological profile compared to the other deprenyl enantiomer (Magyar et al. 1967; Knoll and Magyar 1972).

The two MAO isoforms can be distinguished not only by their selective inhibitors, but they differ in their substrate specificity, as well. Serotonin and noradrenaline are specific substrates of MAO-A explaining the antidepressant and blood pressure increasing effects of its inhibitors (Finberg and Youdim 1983). $\beta$-Phenylethylamine was first identified as MAO-B substrate, since the selective inhibition of MAO-B increased the level of this biogenic amine (Reynolds et al. 1978). Only later on was it revealed that dopamine is also a substrate of MAO-B (Glover et al. 1977). Actually, it was shown to be a substrate of both MAO isoenzymes (O'Carroll et al. 1983).

It was the idea of one of us (P. R.) that an MAO inhibitor with favorable side effect profile was worth trying to treat Parkinson's disease (PD) patients to prevent the serious on-off phenomenon. This suggestion was based on the clinical observations of Birkmayer and Hornykiewicz in the early 1960s that various MAO inhibitors provided mild clinical benefits in the treatment of PD (Birkmayer and Hornykiewicz 1962). However, the potential hypertensive effect of the non-selective irreversible MAO inhibitors restricted their further use. M. Y. informed P. R. about the new selective MAO-B inhibitor compound, selegiline, free from the "cheese effect" and without liver toxicity, which is another problem with some irreversible MAO inhibitors. Although at that time they were not aware that dopamine was a good substrate of MAO-B, furthermore based on rodent studies it was rather regarded as a MAO-A substrate, after some debate P. R., M. Y. and Birkmayer finally concluded that selegiline was worth trying in PD. M. Y. had got some selegiline from Knoll for experimental works and he provided it for starting to treat parkinsonian patients in 1974. The benefit of the treatment with the combination of levodopa and selegiline was first published in 1975 (Birkmayer et al. 1975) and 2 years later its long-term effectiveness was also reported (Birkmayer et al. 1977).

Later on, human post-mortem brain studies revealed that MAO-B isoform was present in the human brain, predominantly in glia (Konradi et al. 1989; Riederer et al. 1987; Collins et al. 1970). In various regions of post-mortem brain of selegiline-treated patients, elevated $\beta$-phenylethylamine and dopamine levels were detected (Riederer et al. 1984; Riederer and Youdim 1986), supporting the dopaminesparing effect of the MAO-B inhibition, which is in line with the clinical findings. Platelet MAO-B inhibition in selegiline-treated patients was also demonstrated (Riederer et al. 1978).

On the proposal of two of us (P. R. and M. Y.) data from PD patients treated for a long time with selegiline in the Lainz Geriatric Hospital, Vienna, were analyzed. The interesting results demonstrated a prolongation of life expectancy for selegiline-treated PD patients first published in 1983 (Birkmayer 1983). The re-analysis of the data by more sophisticated statistical methods showed the same result (Birkmayer et al. 1985). These publications gave a new impetus on preclinical and clinical studies on selegiline aiming at elucidation of its possible neuroprotective effect.

Experimental data from numerous animal and cell culture studies provided evidence that selegiline protects against various neurotoxins, reduces oxidative stress and possesses neurotrophic and antiapoptotic effects. All these properties may contribute to its neuroprotective activity. These preclinical findings were previously thoroughly reviewed (Gerlach et al. 1996; Magyar et al. 2004, 2006; Naoi and Maruyama 2010; Maruyama and Naoi 2013; Szoko et al. 2018).

\section{Clinical studies on selegiline in PD}

The increasing amount of preclinical pharmacological data about the possible neuroprotective effect of selegiline raised the hypothesis that it may slow the progression of PD. To prove this concept, several placebo-controlled randomized clinical trials were initiated from the late 1980s. A smaller study of 54 patients published in 1989 was the first reporting that $10 \mathrm{mg} /$ day selegiline treatment delayed the need for levodopa therapy by about 8 months, which was ascribed to a possible disease progression-slowing effect (Tetrud and Langston 1989). However, it was immediately debated because the bare symptomatic effect of selegiline resulting from its dopamine-sparing effect could not be ruled out (Friedhoff 1990). The first large-scale multicenter controlled clinical trial was initiated in 1987 and it also aimed at determining the disease-modifying effect of selegiline in early $\mathrm{PD}$, which was supposed to be related to the recognized antioxidant property of MAO inhibition. Hydrogen peroxide is one of the products of MAO-catalyzed amine oxidation reaction and it can be converted to further reactive oxygen species resulting in cytotoxicity. The inhibition of MAO activity thus may reduce oxidative stress. As the putative mechanism of neuroprotection was the antioxidant property of selegiline, another antioxidant, tocopherol, was also included in the study in addition to placebo as comparator. Eight hundred untreated PD patients were enrolled into this DATATOP study with primary end point of development of disability, necessitating the introduction of levodopa treatment. In the interim reports evaluating the first 12 months of the trial, a 57\% reduction in the number of subjects reaching 
the primary end point was shown (Parkinson Study Group 1989) and 50\% less patients had to give up full-time employment (Shoulson 1992) in the $10 \mathrm{mg} /$ day selegiline-treated group. The final report was based on the results of a mean $14 \pm 6$ months treatment period. Selegiline therapy delayed the time to end point, the need of levodopa treatment, by about 9 months while tocopherol was ineffective. The mechanism of this beneficial effect was not revealed in the study, but the importance of the antioxidant property was questioned. Regarding symptoms control, assessed by Unified PD Rating Scale (UPDRS) and Activity of Daily Living (ADL) scores, selegiline was most effective in the first 3 months of the therapy. However, 2 months after its withdrawal, the motor performance of patients declined (Parkinson Study Group 1993). These findings clearly indicate the symptomatic benefit of selegiline treatment, but its diseasemodifying effect was not unequivocally proven. In a continuation of the study, selegiline was administered to all patients who did not reach the primary end point over $21 \pm 4$ months of observation. There was no significant difference between the previously selegiline- or placebo-treated groups in the time reaching the end point, the need of starting levodopa. The conclusion of the Parkinson Study Group was that the initial benefit of selegiline treatment was not sustained (Parkinson Study Group 1996). In another continuation, those selegiline-treated patients who required levodopa were rerandomized after 5 years to continue selegiline or change to placebo. During the 2 years follow-up, there was no significant difference in combined end points of development of wearing-off, dyskinesia and on-off fluctuation between the treatment groups. However, assessing the distinct motor disturbances, there were less freezing of gait, wearing-off and on-off fluctuation, but more dyskinesia in the selegiline group, which is consistent with its dopamine-potentiating effect (Shoulson et al. 2002). Further smaller studies were also performed to evaluate the advantage of selegiline monotherapy in early PD. Rapid improvement in several parkinsonian symptoms was demonstrated in several short-term studies (Allain et al. 1993; Mally et al. 1995). Some other trials, similarly to DATATOP study, aimed at evaluation of disease-modifying effect of selegiline. In the Finnish study 54 untreated patients were randomized to $10 \mathrm{mg} /$ day selegiline or placebo. The median time to initiation of levodopa treatment was found about 6 months longer (Myllyla et al. 1991) and the necessary dose of levodopa for the sufficient therapeutic effect was about half in the selegiline group (Myllyla et al. 1993). The levodopa dose-sparing effect was not only maintained, but further increased after the 5 -year follow-up period. Selegiline treatment also reduced the need of additional dopaminergic therapy (slow release levodopa or dopamine agonist) (Myllyla et al. 1997). In a Swedish study of 157 early PD patients, selegiline significantly delayed the need to start levodopa therapy by about
4 months compared to placebo. Furthermore, the advantage of selegiline treatment in UPDRS scores was maintained after 2 months washout period before levodopa was started suggesting its neuroprotective effect (Palhagen et al. 1998). In the continuation of this study, the advantage of selegiline was also maintained after levodopa was started. Patients after 5 years on selegiline and levodopa combination had nearly ten points lower UPDRS scores, while $19 \%$ lower levodopa dose was used compared to levodopa only group (Palhagen et al. 2006). Recently, the benefit of selegiline monotherapy in early PD was also confirmed in a 12-week controlled trial in Japan, further supporting the use of the drug in early Parkinsonism (Mizuno et al. 2017).

These clinical trials unequivocally proved the efficacy of selegiline monotherapy in early PD (Table 1). In addition to symptoms improvement, it delays the introduction of levodopa by 3-9 months and reduces the necessary levodopa dose. Some of the studies also indicate the long-term maintenance of the initial benefit, suggesting neuroprotective effect of early started selegiline treatment.

In addition to the continuations of monotherapy trials, combinational therapy studies were performed, as well. In the first double-blind randomized trial, 112 patients poorly responding to levodopa were subjected to $7.5 \mathrm{mg}$ /day selegiline or placebo combination therapy. After 8 weeks, significantly more patients showed moderate or better improvement when selegiline was added to levodopa (Takahashi et al. 1994). Olanow et al. compared the deterioration of early PD patients receiving levodopa/carbidopa with or without selegiline combination for 12 months, followed by 2 months selegiline washout period. The UPDRS score was deteriorated by $5.8 \pm 1.4$ points in the levodopa/carbidopa group, but remained unaltered $(0.4 \pm 1.3$ point deterioration) in the levodopa/carbidopa + selegiline group. Because of the 2 months selegiline washout before the evaluation, these data suggest its disease-modifying rather than barely symptomatic effect (Olanow et al. 1995). Later on, the study design was criticized because there were no placebo and selegiline only groups. However, according to the authors' answer, for demonstration of benefit of add-on selegiline treatment, the presented design was appropriate (Schulzer 1997). The long-term benefit of addition of selegiline to levodopa treatment was reported by the Norwegian-Danish study group, as well. In the randomized placebo-controlled double-blind trial, combination treatment was continued for 5 years followed by 1-month selegiline washout. At the end of the study, symptoms were less severe and levodopa dose was lower when selegiline was combined to levodopa/ benserazide and no symptom worsening was observed after the washout period (Larsen et al. 1999). SELEDO trial evaluated the long-term outcome of early started combination treatment of levodopa with selegiline or placebo in 160 patients. The primary end point was the need of more 
Table 1 Clinical trials evaluating the effect of selegiline monotherapy in early PD

\begin{tabular}{|c|c|c|c|}
\hline $\begin{array}{l}\text { Design, number of patients (study } \\
\text { name) }\end{array}$ & Studied daily dose & Key findings & References \\
\hline Double-blind RCT, 54 patients & $10 \mathrm{mg}$ selegiline vs. placebo & $\begin{array}{l}8 \text { months delay in the need of initiation } \\
\text { of levodopa therapy }\end{array}$ & Tetrud and Langston (1989) \\
\hline $\begin{array}{l}\text { Double-blind RCT, } 800 \text { patients } \\
\text { (DATATOP_-Interim report) }\end{array}$ & $10 \mathrm{mg}$ selegiline vs. placebo & $\begin{array}{l}57 \% \text { reduction in the number of } \\
\text { patients needing levodopa after } \\
12 \text { months treatment }\end{array}$ & $\begin{array}{l}\text { Parkinson Study Group } \\
\text { (1989), Shoulson (1992) }\end{array}$ \\
\hline Double-blind RCT, 54 patients & $10 \mathrm{mg}$ selegiline vs. placebo & $\begin{array}{l}6 \text { months delay in the need of initiation } \\
\text { of levodopa therapy. } \\
\text { About half dose levodopa was needed } \\
\text { in the selegiline group }\end{array}$ & $\begin{array}{l}\text { Myllyla et al. (1991) } \\
\text { Myllyla et al. (1993) }\end{array}$ \\
\hline Double-blind RCT, 93 patients & $10 \mathrm{mg}$ selegiline vs. placebo & $\begin{array}{l}\text { Improved motor rating and depressive } \\
\text { scores after } 3 \text { months in the selegiline } \\
\text { group }\end{array}$ & Allain et al. (1993) \\
\hline $\begin{array}{l}\text { Double-blind RCT, } 800 \text { patients } \\
\text { (DATATOP_final report) }\end{array}$ & $10 \mathrm{mg}$ selegiline vs. placebo & $\begin{array}{l}9 \text { months delay in the need of initiation } \\
\text { of levodopa therapy }\end{array}$ & Parkinson Study Group (1993) \\
\hline Double-blind RCT, 20 patients & $10 \mathrm{mg}$ selegiline vs. placebo & $\begin{array}{l}\text { Improved motor scores after } 3 \text { weeks in } \\
\text { the selegiline group }\end{array}$ & Mally et al. (1995) \\
\hline $\begin{array}{l}\text { Open label continuation of DATATOP, } \\
310 \text { patients }\end{array}$ & $10 \mathrm{mg}$ selegiline & $\begin{array}{l}\text { No difference in benefit of early and } \\
\text { late start of selegiline }\end{array}$ & Parkinson Study Group (1996) \\
\hline Double-blind RCT, 157 patients & $10 \mathrm{mg}$ selegiline vs. placebo & $\begin{array}{l}4 \text { months delay in the need of initiation } \\
\text { of levodopa therapy. } \\
\text { Improved motor scores were main- } \\
\text { tained after } 2 \text {-month washout }\end{array}$ & Palhagen et al. (1998) \\
\hline Double-blind RCT, 292 patients & $\begin{array}{l}10 \mathrm{mg} \text { selegiline vs. placebo } \\
\text { (dose was escalated over } \\
6 \text { weeks) }\end{array}$ & $\begin{array}{l}\text { Improved motor scores after } 12 \text { weeks } \\
\text { in the selegiline group }\end{array}$ & Mizuno et al. (2017) \\
\hline
\end{tabular}

than $50 \%$ increase in levodopa dose for symptoms control. Almost twice longer time (4.9 vs. 2.6 years) was needed to reach the end point in the selegiline combination group (Przuntek et al. 1999).

In addition to prospective studies, retrospective analysis of patient registers was also performed with contradictory results in terms of effect on disease progression. In one of the early reports, no significant difference between selegiline + levodopa and levodopa alone groups was found regarding Hoehn-Yahr stage and motor symptoms in a period of 5 years. The levodopa dose, however, was lower in case of the combination treatment (Brannan and Yahr 1995). The benefit of long-term and/or early started selegiline treatment is indicated by other retrospective data analyses. Mizuno et al. reported that patients on combination of levodopa and selegiline had lower UPDRS scores compared to levodopa only treated group after about 10 years of disease duration. Adding selegiline to levodopa at this time point, the UPDRS score, although improved after the 4-month combination treatment, did not reach the level seen in patients on early started combination therapy (Mizuno et al. 2010). Another study evaluated the factors affecting disease progression in 687 patients assessing the retardation of Hoehn-Yahr stage transition time. It was found that in early PD, at least 3-year selegiline treatment increased the transition times from stage 2 to 2.5 and 2.5 to 3 (Zhao et al. 2011). Table 2 summarizes the results of studies on combinational therapies.

Contrary to the increased life expectancy of selegilinetreated PD patients in the early observations of Birkmayer (1983) and Birkmayer et al. (1985), the Parkinson's Disease Research Group of the UK reported increased mortality of patients treated with selegiline in combination with levodopa compared to levodopa alone during 5-7 years of follow-up (Lees 1995; Ben-Shlomo et al. 1998). However, meta-analyses of the available clinical trials with selegiline or any MAO-B inhibitors found no increase in mortality (Olanow et al. 1998; Ives et al. 2004; Macleod et al. 2005).

Based on the favorable effects of selegiline in PD, another irreversible MAO-B inhibitor, rasagiline, was introduced into the therapy. It was patented in 1995 (Youdim et al. 1995). Interestingly its methylated derivative, J-508, has already been tested in Knoll's laboratory for MAO inhibition in the 1970 s and was found to be slightly more potent in vivo compared to selegiline (Knoll et al. 1978). The pharmacological properties of rasagiline have been described by one of us (M. Y.). Its MAO inhibitory potential and selectivity in vitro are similar to those of selegiline, but in vivo it is about five times more potent 
Table 2 Clinical trials and retrospective studies evaluating the effect of selegiline combinational therapy in PD

\begin{tabular}{|c|c|c|c|}
\hline $\begin{array}{l}\text { Design, number of patients (study } \\
\text { name) }\end{array}$ & Studied daily dose & Key findings & References \\
\hline Double-blind RCT, 112 patients & $\begin{array}{l}7.5 \mathrm{mg} \text { selegiline vs. placebo in com- } \\
\text { bination with levodopa }\end{array}$ & $\begin{array}{l}\text { More improvement after } 8 \text { weeks in the } \\
\text { selegiline group }\end{array}$ & Takahashi et al. (1994) \\
\hline Retrospective, 82 patients & $\begin{array}{l}10 \text { mg selegiline in combination with } \\
\text { levodopa vs. levodopa alone }\end{array}$ & $\begin{array}{l}\text { No difference in motor scores after } \\
1-5 \text { years } \\
\text { Lower levodopa dose needed after } \\
1-3 \text { years in the selegiline group, no } \\
\text { difference after } 4-5 \text { years }\end{array}$ & Brannan and Yahr (1995) \\
\hline Double-blind RCT, 101 patients & $\begin{array}{l}10 \text { mg selegiline vs. placebo in } \\
\text { combination with levodopa and/or } \\
\text { bromocriptine }\end{array}$ & $\begin{array}{l}\text { Less disease deterioration after } 1 \text { year in } \\
\text { the selegiline group. } \\
\text { Benefit was maintained after } 2 \text {-month } \\
\text { washout }\end{array}$ & Olanow et al. (1995) \\
\hline $\begin{array}{l}\text { Double-blind continuation of Myl- } \\
\text { lyla's study, } 44 \text { patients }\end{array}$ & $\begin{array}{l}10 \mathrm{mg} \text { selegiline vs. placebo in com- } \\
\text { bination to levodopa }\end{array}$ & $\begin{array}{l}\text { Lower levodopa dose needed even after } \\
5 \text { years in the selegiline group }\end{array}$ & Myllyla et al. (1997) \\
\hline Double-blind RCT, 163 patients & $\begin{array}{l}10 \text { mg selegiline vs. placebo in com- } \\
\text { bination with levodopa }\end{array}$ & $\begin{array}{l}\text { Less disease deterioration after } 5 \text { years } \\
\text { in the selegiline group. } \\
\text { Benefit was maintained after 1-month } \\
\text { washout }\end{array}$ & Larsen et al. (1999) \\
\hline Double-blind RCT, 160 patients & $\begin{array}{l}10 \text { mg selegiline vs. placebo in com- } \\
\text { bination with levodopa }\end{array}$ & $\begin{array}{l}\text { About twice longer time to need for } \\
50 \% \text { increase in levodopa dose in the } \\
\text { selegiline group }\end{array}$ & Przuntek et al. (1999) \\
\hline $\begin{array}{l}\text { Double-blind continuation of } \\
\text { DATATOP, } 368 \text { patients }\end{array}$ & $\begin{array}{l}10 \mathrm{mg} \text { selegiline vs. placebo in com- } \\
\text { bination with levodopa }\end{array}$ & $\begin{array}{l}\text { Less wearing-off, freezing of gait and } \\
\text { on-off fluctuation and more dyskine- } \\
\text { sia in the selegiline group }\end{array}$ & Shoulson et al. (2002) \\
\hline $\begin{array}{l}\text { Double-blind continuation of Pal- } \\
\text { hagen's study, } 140 \text { patients }\end{array}$ & $\begin{array}{l}10 \text { mg selegiline vs. placebo in com- } \\
\text { bination with levodopa }\end{array}$ & $\begin{array}{l}\text { Improved motor scores with } 19 \% \text { lower } \\
\text { levodopa dose after } 5 \text { years in the } \\
\text { selegiline group }\end{array}$ & Palhagen et al. (2006) \\
\hline $\begin{array}{l}\text { Retrospective and open label, } 691 \\
\text { patients }\end{array}$ & $\begin{array}{l}10 \text { mg selegiline in combination with } \\
\text { levodopa started within } 5 \text { years of } \\
\text { disease onset vs. levodopa alone. } \\
\text { 4-month open label selegiline treat- } \\
\text { ment initiated in the levodopa alone } \\
\text { group }\end{array}$ & $\begin{array}{l}\text { Improved motor scores after } 10 \text { years in } \\
\text { the selegiline group. } \\
\text { Motor scores were improved after } \\
\text { 4-month selegiline addition, the late } \\
\text { started selegiline was less effective } \\
\text { than the early started one }\end{array}$ & Mizuno et al. (2010) \\
\hline Retrospective, 687 patients & $\begin{array}{l}\text { Effect on disease progression of } \\
\text { various pharmacotherapies with or } \\
\text { without selegiline was evaluated }\end{array}$ & $\begin{array}{l}\text { At least } 3 \text { years selegiline treatment of } \\
\text { early PD patients increased the time } \\
\text { to progression (Hoehn-Yahr stage } \\
\text { transition) }\end{array}$ & Zhao et al. (2011) \\
\hline
\end{tabular}

probably due to pharmacokinetic differences (Youdim et al. 2001). A plethora of further preclinical studies showed rasagiline possessing a similar profile of beneficial effects as selegiline (Weinreb et al. 2010, 2011).

The effectiveness of rasagiline was evaluated in large clinical trials. In the first TEMPO study, its rapid symptomatic effect in early PD was demonstrated (Parkinson Study Group 2002). The results of the open-label extension of this trial indicated that patients on early started rasagiline treatment had better UPDRS score compared to delayed rasagiline administration during 6.5 years of follow-up, suggesting its neuroprotective property (Hauser et al. 2009). These results are similar to those found in selegiline studies. The ADAGIO study was designed to compare the effect of early vs. delayed start of rasagiline in controlled, randomized trial as well, to explore its disease-modifying property. The results, however, are contradictory because the extra benefit of early started therapy was observed only in case of the lower $(1 \mathrm{mg} /$ day) dose (Olanow et al. 2009). The effectiveness of rasagiline in levodopa-treated patients was also proved in the PRESTO and LARGO studies (Parkinson Study Group 2005; Rascol et al. 2005; Elmer 2013).

There are some further recently published data on the neuroprotective effect of the MAO-B inhibitors in PD. During 2007-2013, a large clinical study, NET-PD LS1, was performed, where the primary goal was to evaluate the effect of dietary supplement creatine on the progression of PD. Analysis of data of 1616 participants with mean observation time of 4.1 years revealed that 784 patients receiving MAO-B inhibitor (either selegiline or rasagiline) showed less clinical decline and this benefit was proportional to the cumulative duration of MAO-B inhibitor use. The effect of selegiline and rasagiline 
was not analyzed separately. These results indicate that MAO-B inhibitors may slow the disease progression (Hauser et al. 2017). A recent meta-analysis of the available clinical data confirms the effectiveness of MAO-B inhibitors both in monotherapy and in combination with levodopa. According to its results, selegiline seems to be the most effective MAO-B inhibitor in the combination therapy (Binde et al. 2018).

There are several recent reviews discussing the place of MAO-B inhibitors in the therapy of PD (Riederer and Laux 2011; Fabbrini et al. 2012; Dezsi and Vecsei 2014; Marsili et al. 2017; Dezsi and Vecsei 2017; Riederer and Muller 2018). More and more data suggest the diseasemodifying effect of selegiline or other MAO-B inhibitor therapy, especially when they are started early and used long term (Muller and Mohr 2019). However, because of their symptoms-improving effect, the mechanisms behind the reported clinical benefits could not be unequivocally distinguished so far (Olanow 2009; Teo and Ho 2013).

\section{Selegiline in Alzheimer's disease}

Based on its widely examined neuroprotective property, selegiline was also studied as a potential therapeutic tool for Alzheimer's disease. Some smaller early trials indicated benefit on both cognitive and behavioral symptoms after 3-6 months of treatment. Good tolerability of the drug was also confirmed in these studies (Campi et al. 1990; Monteverde et al. 1990; Mangoni et al. 1991; Finali et al. 1992; Filip and Kolibas 1999). However, there were some trials that showed only slight, clinically not relevant improvements in cognitive and/or behavioral functions (Tariot et al. 1987; Burke et al. 1993). The conclusion of the meta-analyses is that selegiline may provide mild short-term benefit, but its magnitude is not clinically meaningful (Wilcock et al. 2002; Birks and Flicker 2003).

The mild benefit in Alzheimer's disease and the neuroprotective activity shown in preclinical experiments initiated the development of new drug candidates including multitarget compounds. Molecules containing MAO and cholinesterase inhibitory pharmacophores were designed and found having neuroprotective activities on various in vitro and in vivo animal models (Weinreb et al. 2012; Unzeta et al. 2016). However, no clinical data with these compounds have been reported so far.

\section{Delivery forms of selegiline}

Based on the early clinical data of Birkmayer's studies, selegiline was first licensed in Hungary in 1977 by Chinoin Pharmaceuticals under the brand name of Jumex ${ }^{\circledR}$. At that time, it was recommended for alleviation of on-off phenomenon in levodopa-treated PD patients. Some years later, it was also approved in the same therapeutic indication in UK (1982) and in the USA as an orphan drug in 1989.

After the previously discussed clinical trials, the use of selegiline tablets was extended to early monotherapy of PD in the European Union in 1993 and in the USA in 1997. Since then the drug has been marketed worldwide.

After oral administration, selegiline undergoes extensive first pass metabolism and systemic exposure of its metabolites is considerably higher than that of the parent compound. R-Methamphetamine is its primary metabolite that is partially converted to R-amphetamine. In low quantity, desmethylselegiline and selegiline- $N$-oxide are also formed as shown in Fig. 1 (Heinonen et al. 1989; Szoko et al. 1999; Tabi et al. 2003; Shin 1997). These metabolites are pharmacologically active and their contribution to dopaminergic and neuroprotective effects of selegiline was suggested on the basis of extensive preclinical experiments (Szende et al. 2001; Magyar et al. 2004, 2006, 2010). However, Sandler et al. reported that substitution of selegiline treatment by its metabolites (mixture of R-methamphetamine and R-amphetamine) resulted in loss of clinical effect, suggesting no contribution of amphetamines to the clinical benefit in Parkinson's disease (Elsworth et al. 1982; Stern et al. 1983). In clinical trials, selegiline was found to be well tolerated with similar side effect profile to that of placebo and no amphetaminerelated adverse events were observed (Shoulson 1992; Palhagen et al. 1998; Shoulson et al. 2002; Palhagen et al. 2006; Mizuno et al. 2017). The weaker psychotropic effect and dependence liability of R-amphetamines compared to the S-enantiomers were shown in several preclinical studies supporting the findings of the clinical reports (Nickel et al. 1994; Yasar et al. 1993).

To improve its bioavailability, new delivery forms of selegiline were also developed. Orally disintegrating tablets (ODT) are characterized by rapid drug release into saliva. A fraction of the active pharmaceutical ingredient absorbs through the buccal mucosa, avoiding thus the first pass metabolism and providing fast onset of action. According to comparative pharmacokinetic studies of conventional and ODT formulations, selegiline plasma exposure of $1.25 \mathrm{mg}$ ODT was comparable to that of $10 \mathrm{mg}$ conventional tablet. Plasma levels of metabolites were considerably lower in case of the ODT preparation (Clarke et al. 2003a). Comparative 
Fig. 1 Scheme of metabolic transformation of selegiline. The thick arrow indicates the main metabolic step (the formation of R-methamphetamine)

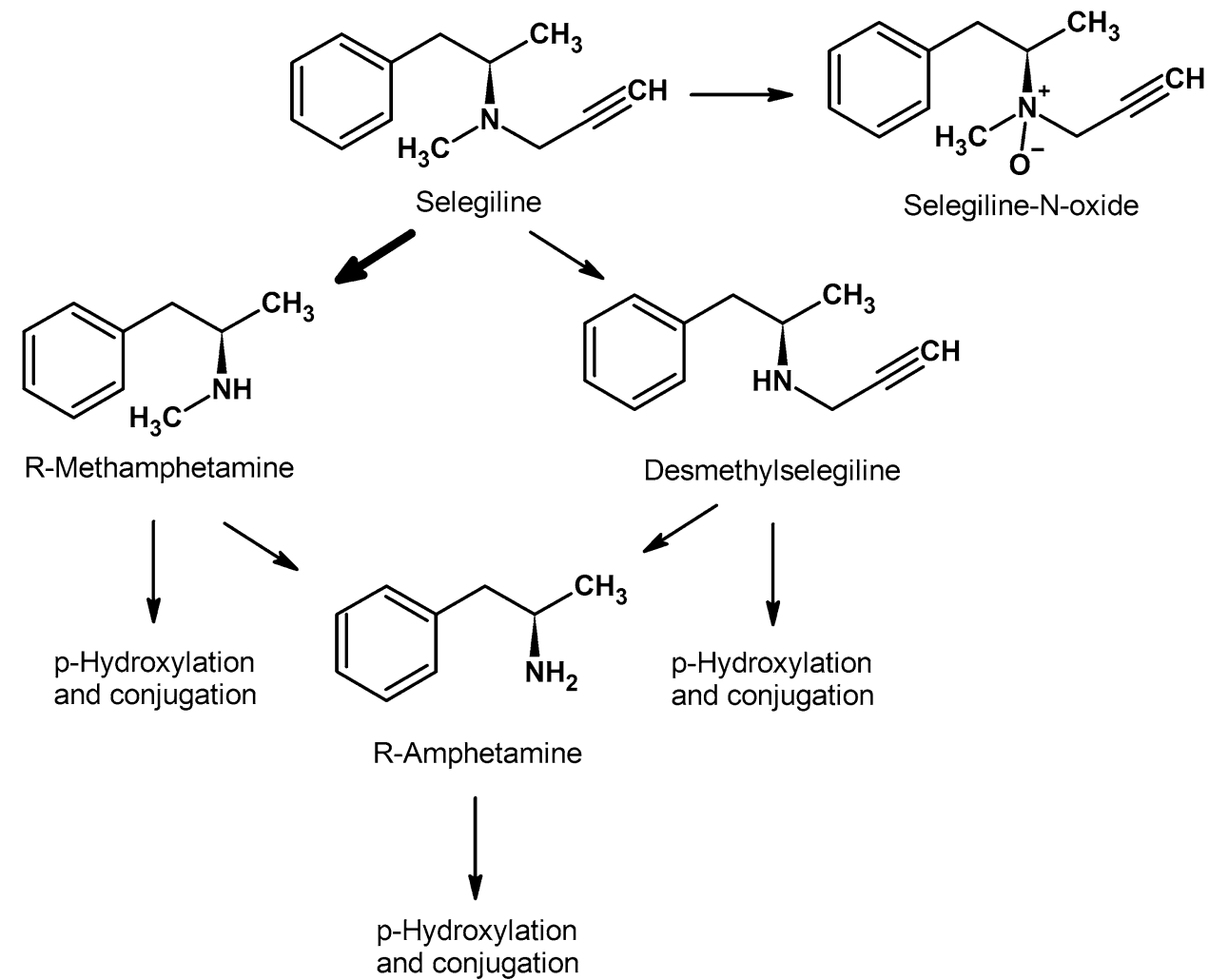

clinical trial of $1.25-2.5 \mathrm{mg}$ selegiline ODT and $10 \mathrm{mg}$ conventional tablets revealed similar efficacy and safety (Clarke et al. 2003b). Based on this and some further clinical data, selegiline ODT was approved by FDA in 2006 and EMA in 2010 as an adjunctive therapy to levodopa in PD. By reviewing the available clinical data, we concluded that the clinical advantage of the clear pharmacokinetic improvement is not well justified. However, the patients' preference, because of the convenience of ODT use, especially in patients with swallowing difficulties, should be acknowledged (Tabi et al. 2013).

Another innovative formulation, selegiline transdermal system (STS), was developed to avoid first pass metabolism. Using STS, the absolute bioavailability increased to $73 \%$ from $4 \%$ observed after oral selegiline administration (Azzaro et al. 2007). However, the high and sustained plasma concentration of selegiline after STS administration results in non-selective inhibition of MAO isoforms in the brain. In early clinical trials, high, probably non-selective, dose of selegiline was found to have antidepressant activity, but the risk of cheese effect hindered its use in this indication (Mann et al. 1989; Sunderland et al. 1994). It was also reported that even chronic daily oral treatment of parkinsonian patients with MAO-B inhibitors reduced plasma MAO-A activity by about $70 \%$ (Bartl et al. 2014), brain data, however, were not available. It was only recently demonstrated that about $33 \%$ inhibition of MAO-A was achieved in human brain after 28-day treatment with STS (6 mg/day) (Fowler et al. 2015). It is in accordance with the results of clinical trials showing its antidepressant effect. Since transdermal absorption avoids the gastrointestinal tract, no considerable intestinal MAO-A inhibition was expected and was first confirmed in an animal study (Mawhinney et al. 2003). Low risk of cheese effect was thus supposed.

Short-term placebo-controlled studies of 6 and 8 weeks in adult patients with major depressive disorder demonstrated statistically significant antidepressant activity of STS compared to placebo. The safety profile of the active compound was similar to that of placebo except for application-site reactions (Bodkin and Amsterdam 2002; Amsterdam 2003; Feiger et al. 2006). There was no hypertensive effect (cheese effect) observed with even consuming tyramine-enriched diet (Blob et al. 2007). The long-term effectiveness of STS was also demonstrated for prevention of relapse in those major depressive patients who initially responded to the preparation. In the STS group, less patients experienced relapse and the time till relapse was also longer compared to placebo (Amsterdam and Bodkin 2006). One 12-week study conducted on adolescents, however, failed to show its superiority to placebo likely due to the high placebo response rate (DelBello et al. 2014). STS has FDA approval from 2006 for the treatment of major depressive disorder in adults.

Transdermal selegiline was also studied for alleviation of nicotine and cocaine dependence. As it increases dopamine 
level in the brain, it was supposed it might reduce craving. Previously in a smaller trial adding oral selegiline to nicotine patch doubled the 52-week continuous abstinence rate, although the difference was not significant. The need of nicotine replacement in the selegiline group was mitigated, probably due to reduced craving (Biberman et al. 2003). However, in placebo-controlled trials STS failed to improve the effectiveness of cognitive behavior intervention in smoking abstinence (Killen et al. 2010; Kahn et al. 2012). In case of cocaine dependence, although preliminary data were promising the controlled clinical trial with STS also failed to show significant effect compared to placebo (Elkashef et al. 2006).

\section{Future perspectives}

After more than half a century history of the first selective MAO-B inhibitor selegiline and its almost 40-year use in the treatment of $\mathrm{PD}$, there is still a continuous interest in studying the unexplored activities of selegiline and other MAO inhibitors.

Promising cardio-metabolic effects of selegiline in animal studies were reported by several research groups. Selegiline showed antioxidant activity and reduced the fat accumulation in the liver of rats on lipid-rich diet (Bekesi et al. 2012). It also improved the metabolism and inflammation in adipose tissue of high-fat, high-sucrose diet-fed rats (Nagy et al. 2018). Its cytoprotective effect was shown in a rabbit model of chronic heart failure by reducing plasma norepinephrine, cardiac oxidative stress and myocyte apoptosis (Qin et al. 2003). MAO-B was also identified as a source of oxidative stress in the vasculature, especially in diabetes (Sturza et al. 2015). MAO-B inhibition by selegiline improved vascular function of human mammary arteries in patients with coronary heart disease regardless of the presence of diabetes (Lighezan et al. 2016). Alleviation of vascular hyperpermeability by selegiline was also demonstrated after hemorrhagic shock (Tharakan et al. 2010) and thermal injury (Whaley et al. 2009).

Potential anticancer activity of MAO inhibitors was also suggested. Overexpression of MAO in various cancer cells was reported and inhibition of the enzyme resulted in antiproliferative effect (Shih 2018; Gaur et al. 2019). Most data come from in vitro experiments, but phenelzine, a nonselective MAO inhibitor, is already in a phase II clinical trial for treatment of non-metastatic recurrent prostate cancer [ClinicalTrials.gov Identifier: NCT02217709], suggesting the clinical relevance of the anticancer activity of MAO inhibitors. High-dose selegiline itself was reported to exert cytotoxic effects on various cancer cell lines in vitro. Millimolar concentration of selegiline was shown to induce apoptotic cell death in melanoma cell line (Szende et al. 2000) and in acute myelogenous leukemia cells by inhibition of the mitochondrial respiration (Ryu et al. 2018). These very high concentrations, however, may suggest MAO-independent mechanisms that remain to be explored.

The several distinct pharmacological activities observed in in vitro and in animal experiments are really interesting, but still far from clinical relevance. The diversity of these effects may indicate either not yet characterized multiple functions of MAO enzyme protein or other targets of MAO inhibitor compounds.

Acknowledgements Open access funding provided by Semmelweis University (SE). The authors acknowledge the financial support of Grants 2018-1.3.1-VKE-2018-00030, GINOP 2.3.2-2015-16-00034 and Ministry of Human Capacities, Hungary Grant: 20391-3/2018/ FEKUSTRAT.

Open Access This article is distributed under the terms of the Creative Commons Attribution 4.0 International License (http://creativeco mmons.org/licenses/by/4.0/), which permits unrestricted use, distribution, and reproduction in any medium, provided you give appropriate credit to the original author(s) and the source, provide a link to the Creative Commons license, and indicate if changes were made.

\section{References}

Allain H, Pollak P, Neukirch HC (1993) Symptomatic effect of selegiline in de novo Parkinsonian patients. The French Selegiline Multicenter Trial. Mov Disord 8(Suppl 1):S36-40

Amsterdam JD (2003) A double-blind, placebo-controlled trial of the safety and efficacy of selegiline transdermal system without dietary restrictions in patients with major depressive disorder. $\mathbf{J}$ Clin Psychiatry 64(2):208-214

Amsterdam JD, Bodkin JA (2006) Selegiline transdermal system in the prevention of relapse of major depressive disorder: a 52-week, double-blind, placebo-substitution, parallel-group clinical trial. J Clin Psychopharmacol 26(6):579-586. https:// doi.org/10.1097/01.jcp.0000239794.37073.70

Azzaro AJ, Ziemniak J, Kemper E, Campbell BJ, VanDenBerg C (2007) Pharmacokinetics and absolute bioavailability of selegiline following treatment of healthy subjects with the selegiline transdermal system $(6 \mathrm{mg} / 24 \mathrm{~h})$ : a comparison with oral selegiline capsules. J Clin Pharmacol 47(10):1256-1267. https ://doi.org/10.1177/0091270007304779

Bartl J, Muller T, Grunblatt E, Gerlach M, Riederer P (2014) Chronic monoamine oxidase-B inhibitor treatment blocks monoamine oxidase-A enzyme activity. J Neural Transm (Vienna) 121(4):379-383. https://doi.org/10.1007/s00702-013-1120-Z

Bekesi G, Tulassay Z, Lengyel G, Schaff Z, Szombath D, Stark J, Marczell I, Nagy-Repas P, Adler I, Dinya E, Racz K, Magyar K (2012) The effect of selegiline on total scavenger capacity and liver fat content: a preliminary study in an animal model. J Neural Transm (Vienna) 119(1):25-30. https://doi. org/10.1007/s00702-011-0666-X

Ben-Shlomo Y, Churchyard A, Head J, Hurwitz B, Overstall P, Ockelford J, Lees AJ (1998) Investigation by Parkinson's Disease Research Group of United Kingdom into excess mortality seen with combined levodopa and selegiline treatment in patients with early, mild Parkinson's disease: further results of randomised trial and confidential inquiry. 
BMJ 316(7139):1191-1196. https://doi.org/10.1136/ bmj.316.7139.1191

Biberman R, Neumann R, Katzir I, Gerber Y (2003) A randomized controlled trial of oral selegiline plus nicotine skin patch compared with placebo plus nicotine skin patch for smoking cessation. Addiction 98(10):1403-1407

Binde CD, Tvete IF, Gasemyr J, Natvig B, Klemp M (2018) A multiple treatment comparison meta-analysis of monoamine oxidase type B inhibitors for Parkinson's disease. Br J Clin Pharmacol 84(9):1917-1927. https://doi.org/10.1111/bcp.13651

Birkmayer W (1983) Deprenyl (selegiline) in the treatment of Parkinson's disease. Acta Neurol Scand Suppl 95:103-105

Birkmayer W, Hornykiewicz O (1962) The L-dihydroxyphenylalanine (L-DOPA) effect in Parkinson's syndrome in man: on the pathogenesis and treatment of Parkinson akinesis. Arch Psychiatr Nervenkr Z Gesamte Neurol Psychiatr 203:560-574

Birkmayer W, Riederer P, Youdim MB, Linauer W (1975) The potentiation of the anti akinetic effect after L-dopa treatment by an inhibitor of MAO-B, Deprenil. J Neural Transm 36(3-4):303-326

Birkmayer W, Riederer P, Ambrozi L, Youdim MB (1977) Implications of combined treatment with 'Madopar' and L-deprenil in Parkinson's disease. A long-term study. Lancet 1(8009):439-443

Birkmayer W, Knoll J, Riederer P, Youdim MB, Hars V, Marton J (1985) Increased life expectancy resulting from addition of L-deprenyl to Madopar treatment in Parkinson's disease: a longterm study. J Neural Transm 64(2):113-127

Birks J, Flicker L (2003) Selegiline for Alzheimer's disease. Cochrane Database Syst Rev. https://doi.org/10.1002/14651858.cd000442

Blob LF, Sharoky M, Campbell BJ, Kemper EM, Gilmor MG, VanDenberg CM, Azzaro AJ (2007) Effects of a tyramine-enriched meal on blood pressure response in healthy male volunteers treated with selegiline transdermal system $6 \mathrm{mg} / 24 \mathrm{~h}$. CNS Spectr 12(1):25-34

Bodkin JA, Amsterdam JD (2002) Transdermal selegiline in major depression: a double-blind, placebo-controlled, parallel-group study in outpatients. Am J Psychiatry 159(11):1869-1875. https ://doi.org/10.1176/appi.ajp.159.11.1869

Brannan T, Yahr MD (1995) Comparative study of selegiline plus L-dopa-carbidopa versus L-dopa-carbidopa alone in the treatment of Parkinson's disease. Ann Neurol 37(1):95-98. https:// doi.org/10.1002/ana.410370117

Burke WJ, Roccaforte WH, Wengel SP, Bayer BL, Ranno AE, Willcockson NK (1993) L-Deprenyl in the treatment of mild dementia of the Alzheimer type: results of a 15-month trial. $\mathrm{J}$ Am Geriatr Soc 41(11):1219-1225

Campi N, Todeschini GP, Scarzella L (1990) Selegiline versus L-acetylcarnitine in the treatment of Alzheimer-type dementia. Clin Ther 12(4):306-314

Clarke A, Brewer F, Johnson ES, Mallard N, Hartig F, Taylor S, Corn TH (2003a) A new formulation of selegiline: improved bioavailability and selectivity for MAO-B inhibition. J Neural Transm (Vienna) 110(11):1241-1255. https://doi.org/10.1007/ s00702-003-0036-4

Clarke A, Johnson ES, Mallard N, Corn TH, Johnston A, Boyce M, Warrington S, MacMahon DG (2003b) A new low-dose formulation of selegiline: clinical efficacy, patient preference and selectivity for MAO-B inhibition. J Neural Transm (Vienna) 110(11):1257-1271. https://doi.org/10.1007/s0070 2-003-0042-6

Collins GG, Sandler M, Williams ED, Youdim MB (1970) Multiple forms of human brain mitochondrial monoamine oxidase. Nature 225(5235):817-820

DelBello MP, Hochadel TJ, Portland KB, Azzaro AJ, Katic A, Khan A, Emslie G (2014) A double-blind, placebo-controlled study of selegiline transdermal system in depressed adolescents. $\mathbf{J}$
Child Adolesc Psychopharmacol 24(6):311-317. https://doi. org/10.1089/cap.2013.0138

Dezsi L, Vecsei L (2014) Safinamide for the treatment of Parkinson's disease. Expert Opin Investig Drugs 23(5):729-742. https:// doi.org/10.1517/13543784.2014.897694

Dezsi L, Vecsei L (2017) Monoamine oxidase B inhibitors in Parkinson's disease. CNS Neurol Disord: Drug Targets 16(4):425439. https://doi.org/10.2174/1871527316666170124165222

Elkashef A, Fudala PJ, Gorgon L, Li SH, Kahn R, Chiang N, Vocci F, Collins J, Jones K, Boardman K, Sather M (2006) Doubleblind, placebo-controlled trial of selegiline transdermal system (STS) for the treatment of cocaine dependence. Drug Alcohol Depend 85(3):191-197. https://doi.org/10.1016/j.drugalcdep .2006.04.010

Elmer LW (2013) Rasagiline adjunct therapy in patients with Parkinson's disease: post hoc analyses of the PRESTO and LARGO trials. Parkinsonism Relat Disord 19(11):930-936. https://doi. org/10.1016/j.parkreldis.2013.06.001

Elsworth JD, Sandler M, Lees AJ, Ward C, Stern GM (1982) The contribution of amphetamine metabolites of (-)-deprenyl to its antiparkinsonian properties. J Neural Transm 54(1-2):105-110

Fabbrini G, Abbruzzese G, Marconi S, Zappia M (2012) Selegiline: a reappraisal of its role in Parkinson disease. Clin Neuropharmacol 35(3):134-140. https://doi.org/10.1097/WNF.0b013 e $318255838 b$

Feiger AD, Rickels K, Rynn MA, Zimbroff DL, Robinson DS (2006) Selegiline transdermal system for the treatment of major depressive disorder: an 8-week, double-blind, placebocontrolled, flexible-dose titration trial. J Clin Psychiatry 67(9):1354-1361

Filip V, Kolibas E (1999) Selegiline in the treatment of Alzheimer's disease: a long-term randomized placebo-controlled trial. Czech and Slovak Senile Dementia of Alzheimer Type Study Group. J Psychiatry Neurosci 24(3):234-243

Finali G, Piccirilli M, Oliani C, Piccinin GL (1992) Alzheimer-type dementia and verbal memory performances: influence of selegiline therapy. Ital J Neurol Sci 13(2):141-148

Finberg JP, Gillman K (2011) Selective inhibitors of monoamine oxidase type B and the "cheese effect". Int Rev Neurobiol 100:169190. https://doi.org/10.1016/b978-0-12-386467-3.00009-1

Finberg JP, Youdim MB (1983) Selective MAO A and B inhibitors: their mechanism of action and pharmacology. Neuropharmacology 22(3 Spec No):441-446

Fowler JS, Logan J, Volkow ND, Shumay E, McCall-Perez F, Jayne M, Wang GJ, Alexoff DL, Apelskog-Torres K, Hubbard B, Carter P, King P, Fahn S, Gilmor M, Telang F, Shea C, Xu Y, Muench L (2015) Evidence that formulations of the selective MAO-B inhibitor, selegiline, which bypass first-pass metabolism, also inhibit MAO-A in the human brain. Neuropsychopharmacology 40(3):650-657. https://doi.org/10.1038/npp.2014.214

Friedhoff AJ (1990) Deprenyl and the progression of Parkinson's disease. Science 249(4966):303-304

Gaur S, Gross ME, Liao CP, Qian B, Shih JC (2019) Effect of Monoamine oxidase A (MAOA) inhibitors on androgen-sensitive and castration-resistant prostate cancer cells. Prostate 79(6):667-677. https://doi.org/10.1002/pros.23774

Gerlach M, Youdim MB, Riederer P (1996) Pharmacology of selegiline. Neurology 47(6 Suppl 3):S137-145

Glover V, Sandler M, Owen F, Riley GJ (1977) Dopamine is a monoamine oxidase B substrate in man. Nature 265(5589):80-81

Hauser RA, Lew MF, Hurtig HI, Ondo WG, Wojcieszek J, Fitzer-Attas CJ (2009) Long-term outcome of early versus delayed rasagiline treatment in early Parkinson's disease. Mov Disord 24(4):564573. https://doi.org/10.1002/mds.22402

Hauser RA, Li R, Perez A, Ren X, Weintraub D, Elm J, Goudreau JL, Morgan JC, Fang JY, Aminoff MJ, Christine CW, Dhall R, 
Umeh CC, Boyd JT, Stover N, Leehey M, Zweig RM, Nicholas AP, Bodis-Wollner I, Willis A, Kieburtz K, Tilley BC (2017) Longer duration of MAO-b inhibitor exposure is associated with less clinical decline in Parkinson's disease: an analysis of NETPD LS1. J Parkinsons Dis 7(1):117-127. https://doi.org/10.3233/ jpd-160965

Heinonen EH, Myllyla V, Sotaniemi K, Lamintausta R, Salonen JS, Anttila M, Savijarvi M, Kotila M, Rinne UK (1989) Pharmacokinetics and metabolism of selegiline. Acta Neurol Scand Suppl 126:93-99

Ives NJ, Stowe RL, Marro J, Counsell C, Macleod A, Clarke CE, Gray R, Wheatley K (2004) Monoamine oxidase type B inhibitors in early Parkinson's disease: meta-analysis of 17 randomised trials involving 3525 patients. BMJ 329(7466):593. https://doi. org/10.1136/bmj.38184.606169.AE

Johnston JP (1968) Some observations upon a new inhibitor of monoamine oxidase in brain tissue. Biochem Pharmacol 17(7):1285-1297

Kahn R, Gorgon L, Jones K, McSherry F, Glover ED, Anthenelli RM, Jackson T, Williams J, Murtaugh C, Montoya I, Yu E, Elkashef A (2012) Selegiline transdermal system (STS) as an aid for smoking cessation. Nicotine Tob Res 14(3):377-382. https://doi. org/10.1093/ntr/ntr143

Killen JD, Fortmann SP, Murphy GM Jr, Hayward C, Fong D, Lowenthal K, Bryson SW, Killen DT, Schatzberg AF (2010) Failure to improve cigarette smoking abstinence with transdermal selegiline + cognitive behavior therapy. Addiction 105(9):16601668. https://doi.org/10.1111/j.1360-0443.2010.03020.x

Knoll J (1979) Selective inhibitors of MAO-B with different pharmacological profiles. In: Magyar K (ed) Monoamine oxidases and their selective inhibition, vol IV. Pergamon Press, Budapest, pp 23-36

Knoll J, Magyar K (1972) Some puzzling pharmacological effects of monoamine oxidase inhibitors. Adv Biochem Psychopharmacol 5:393-408

Knoll J, Ecseri Z, Kelemen K, Nievel J, Knoll B (1965) Phenylisopropylmethylpropinylamine (E-250), a new spectrum psychic energizer. Arch Int Pharmacodyn Ther 155(1):154-164

Knoll J, Ecsery Z, Magyar K, Satory E (1978) Novel (-)deprenylderived selective inhibitors of B-type monoamine oxidase. The relation of structure to their action. Biochem Pharmacol 27(13):1739-1747. https://doi.org/10.1016/00062952(78)90550-6

Konradi C, Kornhuber J, Froelich L, Fritze J, Heinsen H, Beckmann H, Schulz E, Riederer P (1989) Demonstration of monoamine oxidase-A and -B in the human brainstem by a histochemical technique. Neuroscience 33(2):383-400

Larsen JP, Boas J, Erdal JE (1999) Does selegiline modify the progression of early Parkinson's disease? Results from a 5-year study. The Norwegian-Danish Study Group. Eur J Neurol 6(5):539-547

Lees AJ (1995) Comparison of therapeutic effects and mortality data of levodopa and levodopa combined with selegiline in patients with early, mild Parkinson's disease Parkinson's Disease Research Group of the United Kingdom. BMJ 311(7020):1602-1607. https ://doi.org/10.1136/bmj.311.7020.1602

Lighezan R, Sturza A, Duicu OM, Ceausu RA, Vaduva A, Gaspar M, Feier H, Vaida M, Ivan V, Lighezan D, Muntean DM, Mornos C (2016) Monoamine oxidase inhibition improves vascular function in mammary arteries from nondiabetic and diabetic patients with coronary heart disease. Can J Physiol Pharmacol 94(10):1040-1047. https://doi.org/10.1139/cjpp-2015-0580

Macleod AD, Counsell CE, Ives N, Stowe R (2005) Monoamine oxidase B inhibitors for early Parkinson's disease. Cochrane Database Syst Rev. https://doi.org/10.1002/14651858.cd004898.pub2

Magyar K, Vizi ES, Ecseri Z, Knoll J (1967) Comparative pharmacological analysis of the optical isomers of phenyl-isopropyl-methyl-propinylamine (E-250). Acta Physiol Acad Sci Hung 32(4):377-387

Magyar K, Ecseri Z, Bernáth G, Sátory É, Knoll J (1979) Sturctureactivity relationship of selective inhibitors of MAO-B. In: Magyar K (ed) Monoamine oxidases and their selective inhibition. Pergamon Press, Budapest, pp 11-21

Magyar K, Palfi M, Tabi T, Kalasz H, Szende B, Szoko E (2004) Pharmacological aspects of (-)-deprenyl. Curr Med Chem 11(15):2017-2031

Magyar K, Palfi M, Jenei V, Szoko E (2006) Deprenyl: from chemical synthesis to neuroprotection. J Neural Transm Suppl 71:143-156

Magyar K, Szende B, Jenei V, Tabi T, Palfi M, Szoko E (2010) R-Deprenyl: pharmacological spectrum of its activity. Neurochem Res 35(12):1922-1932. https://doi.org/10.1007/s1106 4-010-0238-8

Mally J, Kovacs AB, Stone TW (1995) Delayed development of symptomatic improvement by (-)-deprenyl in Parkinson's disease. J Neurol Sci 134(1-2):143-145

Mangoni A, Grassi MP, Frattola L, Piolti R, Bassi S, Motta A, Marcone A, Smirne S (1991) Effects of a MAO-B inhibitor in the treatment of Alzheimer disease. Eur Neurol 31(2):100-107. https:// doi.org/10.1159/000116655

Mann JJ, Aarons SF, Wilner PJ, Keilp JG, Sweeney JA, Pearlstein T, Frances AJ, Kocsis JH, Brown RP (1989) A controlled study of the antidepressant efficacy and side effects of (-)-deprenyl. A selective monoamine oxidase inhibitor. Arch Gen Psychiatry 46(1):45-50

Marsili L, Marconi R, Colosimo C (2017) Treatment strategies in early Parkinson's Disease. Int Rev Neurobiol 132:345-360. https://doi. org/10.1016/bs.irn.2017.01.002

Maruyama W, Naoi M (2013) "70th Birthday Professor Riederer" induction of glial cell line-derived and brain-derived neurotrophic factors by rasagiline and (-)deprenyl: a way to a diseasemodifying therapy? J Neural Transm (Vienna) 120(1):83-89. https://doi.org/10.1007/s00702-012-0876-x

Mawhinney M, Cole D, Azzaro AJ (2003) Daily transdermal administration of selegiline to guinea-pigs preferentially inhibits monoamine oxidase activity in brain when compared with intestinal and hepatic tissues. J Pharm Pharmacol 55(1):27-34. https://doi. org/10.1211/002235702478

Mizuno Y, Kondo T, Kuno S, Nomoto M, Yanagisawa N (2010) Early addition of selegiline to L-Dopa treatment is beneficial for patients with Parkinson disease. Clin Neuropharmacol 33(1):1-4. https://doi.org/10.1097/WNF.0b013e3181bbf45c

Mizuno Y, Hattori N, Kondo T, Nomoto M, Origasa H, Takahashi R, Yamamoto M, Yanagisawa N (2017) A randomized double-blind placebo-controlled phase III trial of selegiline monotherapy for early parkinson disease. Clin Neuropharmacol 40(5):201-207. https://doi.org/10.1097/wnf.0000000000000239

Monteverde A, Gnemmi P, Rossi F, Monteverde A, Finali GC (1990) Selegiline in the treatment of mild to moderate Alzheimer-type dementia. Clin Ther 12(4):315-322

Muller T, Mohr JD (2019) Pharmacokinetics of monoamine oxidase B inhibitors in Parkinson's disease: current status. Expert Opin Drug Metab Toxicol 15(5):429-435. https://doi. org/10.1080/17425255.2019.1607292

Myllyla VV, Sotaniemi KA, Vuorinen JA, Heinonen EH (1991) Selegiline as a primary treatment of Parkinson's disease. Acta Neurol Scand Suppl 136:70-72

Myllyla VV, Sotaniemi KA, Vuorinen JA, Heinonen EH (1993) Selegiline in de novo parkinsonian patients: the Finnish study. Mov Disord 8(Suppl 1):S41-44

Myllyla VV, Sotaniemi KA, Hakulinen P, Maki-Ikola O, Heinonen EH (1997) Selegiline as the primary treatment of Parkinson's disease-a long-term double-blind study. Acta Neurol Scand 95(4):211-218 
Nagy CT, Koncsos G, Varga ZV, Baranyai T, Tuza S, Kassai F, Ernyey AJ, Gyertyan I, Kiraly K, Olah A, Radovits T, Merkely B, Bukosza N, Szenasi G, Hamar P, Mathe D, Szigeti K, Pelyhe C, Jelemensky M, Onodi Z, Helyes Z, Schulz R, Giricz Z, Ferdinandy $\mathrm{P}$ (2018) Selegiline reduces adiposity induced by high-fat, highsucrose diet in male rats. Br J Pharmacol 175(18):3713-3726. https://doi.org/10.1111/bph.14437

Naoi M, Maruyama W (2010) Monoamine oxidase inhibitors as neuroprotective agents in age-dependent neurodegenerative disorders. Curr Pharm Des 16(25):2799-2817

Nickel B, Szelenyi I, Schulze G (1994) Evaluation of physical dependence liability of L-deprenyl (selegiline) in animals. Clin Pharmacol Ther 56(6 Pt 2):757-767. https://doi.org/10.1038/ clpt.1994.206

O'Carroll AM, Fowler CJ, Phillips JP, Tobbia I, Tipton KF (1983) The deamination of dopamine by human brain monoamine oxidase. Specificity for the two enzyme forms in seven brain regions. Naunyn Schmiedebergs Arch Pharmacol 322(3):198-202

Olanow CW (2009) Can we achieve neuroprotection with currently available anti-parkinsonian interventions? Neurology 72(7 Suppl):S59-64. https://doi.org/10.1212/WNL.0b013e318199068 $\mathrm{b}$

Olanow CW, Hauser RA, Gauger L, Malapira T, Koller W, Hubble J, Bushenbark K, Lilienfeld D, Esterlitz J (1995) The effect of deprenyl and levodopa on the progression of Parkinson's disease. Ann Neurol 38(5):771-777. https://doi.org/10.1002/ana.41038 0512

Olanow CW, Myllyla VV, Sotaniemi KA, Larsen JP, Palhagen S, Przuntek H, Heinonen EH, Kilkku O, Lammintausta R, MakiIkola O, Rinne UK (1998) Effect of selegiline on mortality in patients with Parkinson's disease: a meta-analysis. Neurology 51(3):825-830

Olanow CW, Rascol O, Hauser R, Feigin PD, Jankovic J, Lang A, Langston W, Melamed E, Poewe W, Stocchi F, Tolosa E (2009) A double-blind, delayed-start trial of rasagiline in Parkinson's disease. N Engl J Med 361(13):1268-1278. https://doi. org/10.1056/NEJMoa0809335

Palhagen S, Heinonen EH, Hagglund J, Kaugesaar T, Kontants H, Maki-Ikola O, Palm R, Turunen J (1998) Selegiline delays the onset of disability in de novo parkinsonian patients. Swedish Parkinson Study Group. Neurology 51(2):520-525

Palhagen S, Heinonen E, Hagglund J, Kaugesaar T, Maki-Ikola O, Palm R (2006) Selegiline slows the progression of the symptoms of Parkinson disease. Neurology 66(8):1200-1206. https://doi. org/10.1212/01.wnl.0000204007.46190.54

Parkinson Study Group (1989) Effect of deprenyl on the progression of disability in early Parkinson's disease. N Engl J Med 321(20):1364-1371. https://doi.org/10.1056/nejm19891116321 2004

Parkinson Study Group (1993) Effects of tocopherol and deprenyl on the progression of disability in early Parkinson's disease. N Engl J Med 328(3):176-183. https://doi.org/10.1056/nejm199301 213280305

Parkinson Study Group (1996) Impact of deprenyl and tocopherol treatment on Parkinson's disease in DATATOP subjects not requiring levodopa. Parkinson Study Group. Ann Neurol 39(1):29-36. https://doi.org/10.1002/ana.410390106

Parkinson Study Group (2002) A controlled trial of rasagiline in early Parkinson disease: the TEMPO Study. Arch Neurol 59(12): 1937-1943

Parkinson Study Group (2005) A randomized placebo-controlled trial of rasagiline in levodopa-treated patients with Parkinson disease and motor fluctuations: the PRESTO study. Arch Neurol 62(2):241-248. https://doi.org/10.1001/archneur.62.2.241
Przuntek H, Conrad B, Dichgans J, Kraus PH, Krauseneck P, Pergande G, Rinne U, Schimrigk K, Schnitker J, Vogel HP (1999) SELEDO: a 5-year long-term trial on the effect of selegiline in early Parkinsonian patients treated with levodopa. Eur J Neurol 6(2):141-150

Qin F, Shite J, Mao W, Liang CS (2003) Selegiline attenuates cardiac oxidative stress and apoptosis in heart failure: association with improvement of cardiac function. Eur J Pharmacol 461(2-3):149-158

Rascol O, Brooks DJ, Melamed E, Oertel W, Poewe W, Stocchi F, Tolosa E (2005) Rasagiline as an adjunct to levodopa in patients with Parkinson's disease and motor fluctuations (LARGO, Lasting effect in Adjunct therapy with Rasagiline Given Once daily, study): a randomised, double-blind, parallel-group trial. Lancet 365(9463):947-954. https://doi.org/10.1016/s0140 -6736(05)71083-7

Reynolds GP, Riederer P, Sandler M, Jellinger K, Seemann D (1978) Amphetamine and 2-phenylethylamine in post-mortem Parkinsonian brain after (-)deprenyl administration. J Neural Transm 43(3-4):271-277

Riederer P, Laux G (2011) MAO-inhibitors in Parkinson's disease. Exp Neurobiol 20(1):1-17. https://doi.org/10.5607/en.2011.20.1.1

Riederer P, Muller T (2018) Monoamine oxidase-B inhibitors in the treatment of Parkinson's disease: clinical-pharmacological aspects. J Neural Transm (Vienna) 125(11):1751-1757. https:// doi.org/10.1007/s00702-018-1876-2

Riederer P, Youdim MB (1986) Monoamine oxidase activity and monoamine metabolism in brains of parkinsonian patients treated with L-deprenyl. J Neurochem 46(5):1359-1365

Riederer P, Youdim MB, Rausch WD, Birkmayer W, Jellinger K, Seemann D (1978) On the mode of action of L-deprenyl in the human central nervous system. J Neural Transm 43(3-4):217-226

Riederer P, Jellinger K, Seemann D (1984) Monoamine oxidase and parkinsonism. In: Tipton KF, Dostert P, Strolin-Benedetti M (eds) Monoamine oxidase and disease. Academic Press, London, pp 403-415

Riederer P, Konradi C, Schay V, Kienzl E, Birkmayer G, Danielczyk W, Sofic E, Youdim MB (1987) Localization of MAO-A and MAO-B in human brain: a step in understanding the therapeutic action of L-deprenyl. Adv Neurol 45:111-118

Ryu I, Ryu MJ, Han J, Kim SJ, Lee MJ, Ju X, Yoo BH, Lee YL, Jang Y, Song IC, Chung W, Oh E, Heo JY, Kweon GR (2018) L-Deprenyl exerts cytotoxicity towards acute myeloid leukemia through inhibition of mitochondrial respiration. Oncol Rep 40(6):3869-3878. https://doi.org/10.3892/or.2018.6753

Schulzer M (1997) Treatment of Parkinson's disease: disagreements. Ann Neurol 41(6):833-834. https://doi.org/10.1002/ana.41041 0622

Shih JC (2018) Monoamine oxidase isoenzymes: genes, functions and targets for behavior and cancer therapy. J Neural Transm (Vienna) 125(11):1553-1566. https://doi.org/10.1007/s0070 2-018-1927-8

Shin HS (1997) Metabolism of selegiline in humans. Identification, excretion, and stereochemistry of urine metabolites. Drug Metab Dispos 25(6):657-662

Shoulson I (1992) An interim report of the effect of selegiline (L-deprenyl) on the progression of disability in early Parkinson's disease. The Parkinson Study Group. Eur Neurol 32(Suppl 1):46-53. https://doi.org/10.1159/000116869

Shoulson I, Oakes D, Fahn S, Lang A, Langston JW, LeWitt P, Olanow CW, Penney JB, Tanner C, Kieburtz K, Rudolph A (2002) Impact of sustained deprenyl (selegiline) in levodopa-treated Parkinson's disease: a randomized placebo-controlled extension of the deprenyl and tocopherol antioxidative therapy of parkinsonism trial. Ann Neurol 51(5):604-612. https://doi.org/10.1002/ana.10191 
Stern GM, Lees AJ, Hardie RJ, Sandler M (1983) Clinical and pharmacological problems of deprenyl (selegiline) treatment in Parkinson's disease. Acta Neurol Scand Suppl 95:113-116

Sturza A, Duicu OM, Vaduva A, Danila MD, Noveanu L, Varro A, Muntean DM (2015) Monoamine oxidases are novel sources of cardiovascular oxidative stress in experimental diabetes. Can J Physiol Pharmacol 93(7):555-561. https://doi.org/10.1139/ cjpp-2014-0544

Sunderland T, Cohen RM, Molchan S, Lawlor BA, Mellow AM, Newhouse PA, Tariot PN, Mueller EA, Murphy DL (1994) High-dose selegiline in treatment-resistant older depressive patients. Arch Gen Psychiatry 51(8):607-615

Szende B, Magyar K, Szegedi Z (2000) Apoptotic and antiapoptotic effect of (-)deprenyl and (-)-desmethyl-deprenyl on human cell lines. Neurobiology (Bp) 8(3-4):249-255

Szende B, Bokonyi G, Bocsi J, Keri G, Timar F, Magyar K (2001) Anti-apoptotic and apoptotic action of (-)-deprenyl and its metabolites. J Neural Transm (Vienna) 108(1):25-33. https:// doi.org/10.1007/s007020170094

Szoko E, Kalasz H, Magyar K (1999) Biotransformation of deprenyl enantiomers. Eur J Drug Metab Pharmacokinet 24(4):315-319

Szoko E, Tabi T, Riederer P, Vecsei L, Magyar K (2018) Pharmacological aspects of the neuroprotective effects of irreversible MAO-B inhibitors, selegiline and rasagiline. Parkinson's disease. J Neural Transm (Vienna) 125(11):1735-1749. https://doi.org/10.1007/ s00702-018-1853-9

Tabi T, Magyar K, Szoko E (2003) Chiral characterization of deprenyl$\mathrm{N}$-oxide and other deprenyl metabolites by capillary electrophoresis using a dual cyclodextrin system in rat urine. Electrophoresis 24(15):2665-2673. https://doi.org/10.1002/elps.200305468

Tabi T, Szoko E, Vecsei L, Magyar K (2013) The pharmacokinetic evaluation of selegiline ODT for the treatment of Parkinson's disease. Expert Opin Drug Metab Toxicol 9(5):629-636. https ://doi.org/10.1517/17425255.2013.781152

Takahashi M, Yuasa R, Imai T, Tachibana H, Yorifuji S, Nakamura Y, Ogawa N (1994) Selegiline (L-deprenyl) and L-dopa treatment of Parkinson's disease: a double-blind trial. Intern Med 33(9):517-524

Tariot PN, Sunderland T, Weingartner H, Murphy DL, Welkowitz JA, Thompson K, Cohen RM (1987) Cognitive effects of L-deprenyl in Alzheimer's disease. Psychopharmacology 91(4):489-495

Teo KC, Ho SL (2013) Monoamine oxidase-B (MAO-B) inhibitors: implications for disease-modification in Parkinson's disease. Transl Neurodegener 2(1):19. https://doi. org/10.1186/2047-9158-2-19

Tetrud JW, Langston JW (1989) The effect of deprenyl (selegiline) on the natural history of Parkinson's disease. Science 245(4917):519-522

Tharakan B, Whaley JG, Hunter FA, Smythe WR, Childs EW (2010) (-)-Deprenyl inhibits vascular hyperpermeability after hemorrhagic shock. Shock 33(1):56-63. https://doi.org/10.1097/ SHK.0b013e3181a7fb7c
Unzeta M, Esteban G, Bolea I, Fogel WA, Ramsay RR, Youdim MB, Tipton KF, Marco-Contelles J (2016) Multi-target directed donepezil-like ligands for Alzheimer's disease. Front Neurosci 10:205. https://doi.org/10.3389/fnins.2016.00205

Varga E, Tringer L (1967) Clinical trial of a new type promptly acting psychoenergetic agent (phenyl-isopropyl-methylpropionyl-HCl, "E-250"). Acta Med Acad Sci Hung 23(3):289-295

Weinreb O, Amit T, Bar-Am O, Youdim MB (2010) Rasagiline: a novel anti-Parkinsonian monoamine oxidase-B inhibitor with neuroprotective activity. Prog Neurobiol 92(3):330-344. https://doi. org/10.1016/j.pneurobio.2010.06.008

Weinreb O, Amit T, Riederer P, Youdim MB, Mandel SA (2011) Neuroprotective profile of the multitarget drug rasagiline in Parkinson's disease. Int Rev Neurobiol 100:127-149. https://doi. org/10.1016/b978-0-12-386467-3.00007-8

Weinreb O, Amit T, Bar-Am O, Youdim MB (2012) Ladostigil: a novel multimodal neuroprotective drug with cholinesterase and brain-selective monoamine oxidase inhibitory activities for Alzheimer's disease treatment. Curr Drug Targets 13(4):483-494

Whaley JG, Tharakan B, Smith B, Hunter FA, Childs EW (2009) (-)-Deprenyl inhibits thermal injury-induced apoptotic signaling and hyperpermeability in microvascular endothelial cells. J Burn Care Res 30(6):1018-1027. https://doi.org/10.1097/BCR.0b013 e3181bfb825

Wilcock GK, Birks J, Whitehead A, Evans SJ (2002) The effect of selegiline in the treatment of people with Alzheimer's disease: a meta-analysis of published trials. Int J Geriatr Psychiatry 17(2):175-183

Yasar S, Schindler CW, Thorndike EB, Szelenyi I, Goldberg SR (1993) Evaluation of the stereoisomers of deprenyl for amphetaminelike discriminative stimulus effects in rats. J Pharmacol Exp Ther 265(1):1-6

Youdim M, Finberg JP, Levy R, Sterling J, Lerner D (1995) R-Enantiomers of $N$-propargyl-amino indian compounds. Their preparation and pharmaceuticals containing them. US Patent 5,457,133

Youdim MB, Gross A, Finberg JP (2001) Rasagiline [ $N$-propargyl$1 \mathrm{R}(+)$-aminoindan], a selective and potent inhibitor of mitochondrial monoamine oxidase B. Br J Pharmacol 132(2):500-506. https://doi.org/10.1038/sj.bjp.0703826

Zhao YJ, Wee HL, Au WL, Seah SH, Luo N, Li SC, Tan LC (2011) Selegiline use is associated with a slower progression in early Parkinson's disease as evaluated by Hoehn and Yahr Stage transition times. Parkinsonism Relat Disord 17(3):194-197. https:// doi.org/10.1016/j.parkreldis.2010.11.010

Publisher's Note Springer Nature remains neutral with regard to jurisdictional claims in published maps and institutional affiliations. 